\title{
Serapan Hara Dan Hasil Jagung (Zea Mays L.) Akibat \\ Pemberian Berbagai Jenis Dan Metode Perhitungan Kebutuhan Kapur Pada Ultisol
}

\author{
(Nutrient Absorption and Corn Result (Zea Mays L.) Due to The Growth of Types And \\ Calculation Methods on Ultisol)
}

\author{
Arief Maulana ${ }^{1}$, Zuraida $^{1}$, Muyassir $^{{ }^{*}}$ \\ ${ }^{1}$ Program Studi Ilmu Tanah, Fakultas Pertanian, Universitas Syiah Kuala
}

\begin{abstract}
Abstrak. Penelitian ini bertujuan untuk melihat metode kebutuhan kapur dan jenis kapur yang efektif terhadap serapan hara dan hasil jagung (Zea mays L.) pada Ultisol dengan menggunakan Rancangan Acak Kelompok (RAK) Faktorial dengan 9 perlakuan dan ulangan sebanyak 3 kali sehingga didapatkan 27 satuan unit percobaan. Faktor yang diteliti adalah metode perhitungan kebutuhan kapur sebagai faktor 1 dan jenis kapur sebagai faktor 2. Faktor 1 metode perhitungan kebutuhan kapur terdiri dari 3 taraf yaitu: metode Corey (M1), metode berdasarkan Aldd (M2), dan metode Knooti (M3). Faktor 2 adalah jenis kapur yang terdiri dari 3 taraf yaitu: dolomit (K1), kalsit (K2), dan gypsum (K3). Untuk melihat perbedaan hasil perlakuan digunakan uji $\mathrm{F}$ dan dilanjutkan dengan uji $\left(\mathrm{BNT}_{0,05}\right)$. Hasil penelitian didapatkan serapan hara dan komponen hasil jagung yang bervariasi secara nyata akibat interaksi metode perhitungan kebutuhan kapur. Gypsum yang dihitung dengan metode Corey menghasilkan kadar dan serapan tanaman jagung yang lebih baik dari jenis kapur yang dihitung dengan metode perhitungan lainnya, demikian juga halnya dengan komponen hasil jagung yang ditanam pada Ultisol.
\end{abstract}

Kata Kunci: Metode, Serapan Hara, Hasil Jagung, Ultisol

\begin{abstract}
The study aims to see the lime and lime lime requirement method that was effective against nutrient uptake and corn yield (Zea mays L.) on Ultisol using Factorial Randomized Block Design (RAK) with 9 treatments and replicates 3 times so that 27 units of experiments. Factor of research is calculation method of lime requirement as factor 1 and lime type as factor 2. Factor 1 calculation method of lime requirement consists of 3 levels that is: Corey method (M1), method based on Aldd (M2), and Knooti (M3) method. Factor 2 is a type of lime which consists of 3 levels, namely: dolomite (K1), calcite (K2), and gypsum (K3). To see difference between treatment result used F tests and continued with test (BNT0,05). The results showed nutrient uptake and corn yield components that varied significantly due to the interaction of calculation method of lime requirement. Gypsum calculated by Corey method yields better corn absorption rate and absorption of lime species calculated by other calculation methods, as well as corn components grown on Ultisol.
\end{abstract}

Keywords: Methods, Nutrient Absorption, Corn Yield, Ultisol

\section{PENDAHULUAN}

Jagung merupakan tanaman serelia yang termasuk bahan pangan penting karena merupakan sumber karbohidrat setelah beras (Purwono et al., 2011). Sebagai komoditas palawija utama di Indonesia ditinjau dari aspek pengusahaan dan penggunaan hasilnya, jagung dijadikan sebagai bahan baku pangan dan pakan (Sarasutha 2002).

Menurut Hardjowigeno et al (1992) di Indonesia, Ultisol adalah tanah yang menduduki luasan terbesar dan sebagian besar merupakan hutan tropika dan alang-alang. Ultisol merupakan lahan potensial untuk dikembangkan sebagai lahan pertanian, akan tetapi kurang produktif apabila ditinjau dari kesuburan tanah. Umumnya tanah tersebut mempunyai $\mathrm{pH}$ yang sangat masam hingga agak masam, yaitu sekitar 4,1-5,5.

Notohadiprawiro (1983) berpendapat bahwa, tindakan pengapuran merupakan salah satu alternatif yang dapat dilakukan untuk mengatasi masalah pada tanah Ultisol. Pengapuran 
dapat meningkatkan $\mathrm{pH}$ tanah serta dapat menekan kelarutan unsur-unsur yang meracuni tanaman. Dengan pengapuran berarti menambahkan unsur yang mengandung $\mathrm{Ca}$ ke dalam tanah sehingga dapat meningkatkan ketersediaannya. Pengapuran lahan pertanian umumnya lebih ditujukan untuk perbaikan kondisi tanah dalam hubungannya dengan $\mathrm{pH}$, netralisasi $\mathrm{Al}$ serta untuk mengatasi kekurangan kalsium dalam tanah. Pemberian kapur dapat mengatasi masalah kemasaman tanah dan juga menjamin tanaman dapat bertahan hidup dan membantu meningkatkan produktivitas (Amien et al., 1990).

Salah satu kendala tanah dalam penyediaan hara dan serapan hara oleh tanaman adalah kadar $\mathrm{pH}$ tanah yang terlalu masam. Nilai $\mathrm{pH}$ tanah merupakan faktor utama yang mempengaruhi daya larut dan mempengaruhi ketersediaan hara tanaman (Gardner, 1991). Hara tanaman lebih tersedia pada $\mathrm{pH}$ 6-7, $\mathrm{pH} 5,5$ menjadi batas toleransi tanaman dalam pertumbuhan. Peranan kapur dalam serapan unsur hara berpengaruh terhadap $\mathrm{pH}$ tanah dimana nilai $\mathrm{pH}$ tanah yang diperlakukan dengan kapur lebih tinggi daripada tanah yang tidak diberi kapur. Menurut (Hardjowigeno, 1992) untuk menentukan banyaknya kapur yang diperlukan setiap hektarnya bisa menggunakan beberapa metode perhitungan kebutuhan kapur diantaranya metode Al-dd, Corey, SMP dan Knooti.

Berdasarkan uraian diatas, dapat diketahui bahwa upaya untuk meningkatkan produksi jagung di tanah Ultisol dapat dilakukan melalui pengelolaan tanaman yang sesuai dan manipulasi tanah yang tepat. Kebutuhan kapur memegang peranan yang sangat penting dalam meningkatkan produksi jagung di tanah Ultisol. Oleh karena itu, penulis melakukan penelitian mengenai pemberian berbagai jenis kapur dengan metode pemberian kapur yang berbeda pada Ultisol dan hubungannya dengan serapan hara dan hasil jagung (Zea mays L.).

\section{METODE PENELITIAN}

Penelitian ini dilaksanakan di Kebun Percobaan Fakultas Pertanian Universitas Syiah Kuala, dengan pengambilan bahan tanah Ultisol di Desa Aweuk Kecamatan Jantho Kabupaten Aceh Besar. Analisis bahan tanah dan serapan hara di lakukan di Laboratorium Tanah dan Tanaman Fakultas Pertanian Universitas Syiah Kuala. Pelaksanaan penelitian dimulai dari bulan Juli sampai dengan Oktober 2017.

\section{MATERI DAN METODE}

Bahan tanah Ultisol yang berasal dari Desa Aweuk, Kecamatan Jantho, Kabupaten Aceh Besar, varietas Bisi 222, dolomit, kalsit, gypsum dan sejumlah bahan kimia yang berasal dari Laboratorium Penelitian Tanah dan Tanaman Fakultas Pertanian Universitas Syiah Kuala, Darussalam Banda Aceh.

\section{Metode Penelitian \\ Analisis Statistik}

Penelitian ini menggunakan Rancangan Acak Kelompok (RAK) Faktorial dengan 9 perlakuan dan ulangan sebanyak 3 kali sehingga terdapat 27 satuan unit percobaan (SUP). Faktor yang diteliti adalah metode kebutuhan kapur dan jenis kapur. Faktor 1 metode perhitungan kebutuhan kapur terdiri dari 3 taraf yaitu: metode Corey (M1), metode berdasarkan Aldd (M2), dan metode Knooti (M3). Faktor 2 adalah jenis kapur yang terdiri dari 3 taraf yaitu: dolomit (K1), kalsit (K2), dan gypsum (K3). 


\section{Pelaksanaan Penelitian}

Persiapan Media Tanam

Permukaan tanah dibersihkan dari serasah tanaman, kemudian bahan tanah diambil dengan menggunakan cangkul pada tanah lapisan atas (top soil) dengan kedalaman berkisar antara 0-20 cm. Bahan tanah tersebut dikering anginkan dan dihancurkan serta diayak dengan ayakan yang berukuran diameter lubang $2 \mathrm{~mm}$ kemudian dilakukan analisis awal beberapa sifat kimia tanah. Kapur yang digunakan adalah dolomit, kalsit dan gypsum. Selanjutnya dilakukan perhitungan kebutuhan kapur sesuai dengan masing-masing metode perhitungan kebutuhan kapur berdasarkan tabel susunan kombinasi perlakuan dengan berat masing-masing tanah $15 \mathrm{~kg} /$ polybag. Setelah dihitung dilakukan pengapuran dan kemudian di inkubasi selama 2 minggu agar tanah bereaksi dengan kapur dan dilanjutkan ke tahap penanaman.

\section{Pelaksanaan Kegiatan}

Media tanam yang telah di inkubasi selama 2 minggu, lalu ditanami 2 benih jagung pada setiap polybagnya. Setelah tanaman tumbuh dalam 1 minggu, hanya satu tanaman jagung saja yang dipelihara hingga panen. Pemberian pupuk dasar juga dilakukan pada saat penanaman yaitu pupuk Urea $(3,33 \mathrm{~g})$ yang diberikan pada saat tanaman berumur 1 minggu setelah tanam dan 3 minggu setelah tanam, untuk pupuk TSP $(1,63 \mathrm{~g})$ dan $\mathrm{KCl}(2,50 \mathrm{~g})$ diberikan seluruhnya pada saat 1 minggu setelah tanam. Untuk pemeliharaan tanaman dilakukan penyiraman setiap pagi dan sore hari. Juga dilakukan penyiangan dan penggemburan tanah dalam polybag untuk mencegah gulma tumbuh. Panen dilakukan setelah jagung matang yang ditandai dengan tongkol mulai mengering dan menguning yaitu dengan umur berkisar antara 80-90 hari setelah tanam.

\section{Pengamatan}

Parameter serapan hara tanaman yang diamati di laboratorium adalah Nitrogen (\%), Fosfor (\%) dan Kalium (\%). Komponen hasil jagung yang diamati yaitu panjang tongkol jagung $(\mathrm{cm})$, berat tongkol jagung berkelobot $(\mathrm{g})$, berat tongkol jagung tanpa kelobot $(\mathrm{g})$, diameter tongkol jagung berkelobot $(\mathrm{cm})$ dan diameter tongkol jagung tanpa kelobot $(\mathrm{cm})$.

\section{HASIL DAN PEMBAHASAN \\ Karakteristik Tanah Awal}

Analisis tanah awal dilakukan untuk menentukan tingkat kecocokan tanah terhadap aktivitas pertanian, berikut adalah hasil analisis awal kimia Ultisol yang digunakan pada penelitian ini disajikan pada Tabel 1.

Tabel 1. Hasil Analisis Awal Sifat Kimia Ultisol

\begin{tabular}{lll}
\hline No. & Macam Analisis dan Metode & Hasil Analisis \\
\hline 1. & Tekstur Tanah : & \\
2. & Pasir & $42 \%$ \\
3. & Debu & $29 \%$ \\
4. & Liat & $29 \%$ \\
5. & Kelas Tekstur & 1 lempung berliat \\
6. & pH H $\mathrm{O}$ & 5,35 \\
7. & pH KCl & 3,87 \\
8. & C-Organik & $0,66 \%$ \\
9. & N-total & $0,24 \%$ \\
10. & P-tersedia & $2,85 \mathrm{mg} \mathrm{kg}^{-1}$ \\
11. & Kapasitas Tukar Kation & $15,60 \mathrm{cmol} \mathrm{kg}^{-1}$ \\
12. & Kejenuhan Basa & $47,82 \%$ \\
13. & Al-dd & $1,00 \mathrm{cmol} \mathrm{kg}^{-1}$ \\
\hline
\end{tabular}

Serapan Hara dan Hasil Jagung (Zea mays L.) Akibat Pemberian Berbagai Jenis dan Metode Perhitungan Kebutuhan Kapur pada Ultisol 
Hasil analisis awal yang didapat apabila merujuk pada kriteria penilaian sifat kimia dari Pusat Penelitian Tanah (1983), maka tanah pada lokasi penelitian memiliki nilai pH yang bersifat masam, karena berada pada rentang $\mathrm{pH}$ 4,5-5,5. Kandungan C-organik yang diperoleh menurut PPT (1983) pada area tersebut tergolong sangat rendah yaitu dibawah $1 \%$. Selanjutnya nilai P-tersedia yang didapat yaitu $2,85 \mathrm{mg} \mathrm{kg}^{-1}$ tergolong dalam kategori sangat rendah.

Nilai KTK yang didapat pada analisis awal ini termasuk dalam kategori rendah, karena berada pada rentang nilai 5-16 me/100g. Sedangkan kandungan Al-dd yang diperoleh adalah 1,00 dengan kategori termasuk rendah.

\section{Serapan Hara}

\section{Nitrogen (N)}

Hasil analisis sidik ragam menunjukkan bahwa jenis kapur berpengaruh tidak nyata terhadap kadar dan serapan $\mathrm{N}$ tanaman jagung. Dosis kapur dengan beberapa metode memperlihatkan pengaruh nyata terhadap kadar $\mathrm{N}$ dan berpengaruh tidak nyata terhadap serapan $\mathrm{N}$, sedangkan pengaruh interaksi antara jenis kapur dan dosis kapur dengan metode perhitungan kebutuhan kapur berpengaruh tidak nyata. Rata-rata kadar dan serapan $\mathrm{N}$ akibat pengaruh jenis kapur dapat dilihat pada Tabel 2, sedangkan rata-rata kadar dan serapan $\mathrm{N}$ akibat pengaruh metode perhitungan kebutuhan kapur ditunjukkan pada Tabel 3.

Tabel 2. Rata-rata Kadar dan Serapan Nitrogen Tanaman Jagung Akibat Pemberian Beberapa Jenis Kapur

\begin{tabular}{lcc}
\hline \multirow{2}{*}{ Jenis Kapur } & \multicolumn{2}{c}{ Parameter Pengujian } \\
\cline { 2 - 3 } & Kadar N $(\%)$ & Serapan N $(\mathrm{g})$ \\
\hline 1. Dolomit & 1,44 & 0,17 \\
2. Kalsit & 1,32 & 0,18 \\
3. Gypsum & 1,45 & 0,24 \\
\hline BNT $_{0,05}$ & - & - \\
\hline
\end{tabular}

Tabel 3. Rata-rata Kadar dan Serapan Nitrogen Tanaman Jagung Akibat Pengaruh Dosis Kapur Dengan Metode Perhitungan Kebutuhan Kapur

\begin{tabular}{|c|c|c|}
\hline \multirow{2}{*}{$\begin{array}{c}\text { Dosis Kapur } \\
\text { Dengan Metode }\end{array}$} & \multicolumn{2}{|c|}{ Parameter Pengujian } \\
\hline & Kadar N (\%) & Serapan N (g) \\
\hline 1. Corey & $1,59 \quad \mathrm{~b}$ & 0,17 \\
\hline 2. Al-dd & 1,42 a & 0,20 \\
\hline 3. Knooti & 1,20 & 0,21 \\
\hline $\mathrm{BNT}_{0,05}$ & 0,16 & - \\
\hline
\end{tabular}

Berdasarkan Tabel 3, rata-rata kadar $\mathrm{N}$ tanaman tertinggi dijumpai pada metode Corey $(1,45 \%)$ yang berbeda nyata dengan metode Al-dd (1,42\%) metode Knooti $(1,20 \%)$. Ratarata serapan nitrogen akibat perlakuan metode perhitungan kebutuhan kapur tertinggi di jumpai pada metode Knooti $(0,21 \mathrm{~g})$, sedangkan yang terendah yaitu metode Corey $(0,17 \mathrm{~g})$. Menurut Jones (1967) kadar N (\%) pada tanaman jagung yang memiliki kadar hara > 3,75 dikategorikan sangat tinggi, 3,51 - 3,75 dikategorikan tinggi, 2,76 - 3,50 dikategorikan sedang, 2,46 - 2,75 dikategorikan rendah dan jika nilai nitrogen $<2,45$ dikategorikan sangat rendah. Maka hasil dari rata-rata pada Tabel 5 dan 6 termasuk kriteria yang sangat rendah

Serapan Hara dan Hasil Jagung (Zea mays L.) Akibat Pemberian Berbagai Jenis dan Metode Perhitungan Kebutuhan Kapur pada Ultisol 
dikarenakan memiliki nilai kadar hara $<2,45 \%$. Menurut Sanchez (1992) serapan N sangat tergantung dari kadar nitrogen dan berat brangkasan kering tanaman. Faktor yang mempengaruhi serapan $\mathrm{N}$ adalah diantaranya $\mathrm{pH}$ tanah, daya serap tanaman, porositas dan permeabilitas tanah serta penyebaran akar tanaman (Purbajanti et al., 2002). Rendahnya konsentrasi nitrogen ini diduga berhubungan dengan remobilisasi senyawa bernitrogen untuk ditranslokasikan ke tempat pemanfaatan yang baru dengan berakhirnya fase vegetative, karena nitrogen merupakan unsur yang bersifat mobil dalam tanaman (Tisdale et al., 1985; Gardner et al., 1991).

\section{Fosfor (P)}

Hasil analisis sidik ragam menunjukkan bahwa jenis kapur, dosis kapur dengan metode perhitungan kebutuhan kapur dan interaksi antara jenis kapur dan dosis kapur dengan beberapa metode berpengaruh tidak nyata terhadap kadar dan serapan $\mathrm{P}$ tanaman jagung. Rata-rata kadar dan serapan $\mathrm{P}$ akibat pengaruh jenis kapur dapat dilihat pada Tabel 4, sedangkan rata-rata kadar dan serapan $\mathrm{P}$ akibat pengaruh metode perhitungan kebutuhan kapur ditunjukkan pada Tabel 5.

Tabel 4. Rata-rata Kadar dan Serapan Fosfor Tanaman Jagung Akibat Pemberian Beberapa Jenis Kapur

\begin{tabular}{lcc}
\hline \multirow{2}{*}{ Jenis Kapur } & \multicolumn{2}{c}{ Parameter Pengujian } \\
\cline { 2 - 3 } & Kadar P $(\%)$ & Serapan P $(\mathrm{g})$ \\
\hline 1. Dolomit & 0,24 & 0,03 \\
2. Kalsit & 0,24 & 0,03 \\
3. Gypsum & 0,24 & 0,04 \\
\hline BNT $_{0,05}$ & - & - \\
\hline
\end{tabular}

Tabel 5. Rata-rata Kadar dan Serapan Fosfor Tanaman Jagung Akibat Pengaruh Dosis Kapur Dengan Metode Perhitungan Kebutuhan Kapur

\begin{tabular}{lcc}
\hline \multicolumn{1}{c}{ Dosis Kapur } & \multicolumn{2}{c}{ Parameter Pengujian } \\
\cline { 2 - 3 } Dengan Metode & Kadar P $(\%)$ & Serapan P $(\mathrm{g})$ \\
\hline 1. Corey & 0,26 & 0,03 \\
2. Al-dd & 0,23 & 0,03 \\
3. Knooti & 0,22 & 0,04 \\
\hline BNT $_{0,05}$ & - & - \\
\hline
\end{tabular}

Rata-rata kadar $\mathrm{P}$ akibat perlakuan metode perhitungan kebutuhan kapur tertinggi dijumpai pada metode Corey $(0,26 \%)$ dan yang terendah yaitu metode Knooti $(0,22 \%)$. Sedangkan rata-rata serapan $\mathrm{P}$ dijumpai angka yang sama pada dua perlakuan metode kebutuhan kapur yaitu metode Corey dan Knooti (0,03 g). Menurut Jones (1967) kadar P (\%) pada tanaman jagung yang memiliki kadar hara > 0,50 dikategorikan sangat tinggi, 0,41 - 0,50 dikategorikan tinggi, 0,25 - 0,40 dikategorikan sedang, 0,16 - 0,24 dikategorikan rendah dan jika nilai fosfor $<0,15$ dikategorikan sangat rendah. Maka hasil dari rata-rata pada Tabel 7 dan 8 termasuk kriteria yang rendah dikarenakan memiliki nilai kadar hara 0,16-0,24\% . Hal ini diduga karena unsur hara $\mathrm{N}$ yang juga rendah, sehingga menjadi pembatas unsur hara $\mathrm{P}$ dan menyebabkan kurang optimumnya hasil yang didapatkan. Menurut Wang et al., (2007)

Serapan Hara dan Hasil Jagung (Zea mays L.) Akibat Pemberian Berbagai Jenis dan Metode Perhitungan Kebutuhan Kapur pada Ultisol 
dan Homer (2008) bahwa kondisi pertumbuhan tanaman yang baik akibat tercukupinya hara $\mathrm{N}$ akan menyebabkan tanaman mampu menyerap $\mathrm{P}$ lebih efektif.

\section{Kalium (K)}

Hasil analisis sidik ragam menunjukkan bahwa jenis kapur berpengaruh tidak nyata terhadap kadar dan serapan $\mathrm{K}$ tanaman jagung. Dosis kapur dengan beberapa metode memperlihatkan pengaruh nyata terhadap serapan $\mathrm{K}$ dan berpengaruh tidak nyata terhadap kadar K, sedangkan pengaruh interaksi antara jenis kapur dan dosis kapur dengan metode perhitungan kebutuhan kapur berpengaruh tidak nyata. Rata-rata kadar dan serapan $\mathrm{K}$ akibat pengaruh jenis kapur dapat dilihat pada Tabel 6, sedangkan rata-rata kadar dan serapan $\mathrm{K}$ akibat pengaruh metode perhitungan kebutuhan kapur ditunjukkan pada Tabel 7.

Tabel 6. Rata-rata Kadar dan Serapan Kalium Tanaman Jagung Akibat Pemberian Beberapa Jenis Kapur

\begin{tabular}{lcc}
\hline \multirow{2}{*}{ Jenis Kapur } & \multicolumn{2}{c}{ Parameter Pengujian } \\
\cline { 2 - 3 } & Kadar K $(\%)$ & Serapan K $(\mathrm{g})$ \\
\hline 1. Dolomit & 1,38 & 0,16 \\
2. Kalsit & 1,31 & 0,18 \\
3. Gypsum & 1,40 & 0,23 \\
\hline $\mathrm{BNT}_{0,05}$ & - & - \\
\hline
\end{tabular}

Tabel 7. Rata-rata Kadar dan Serapan Kalium Tanaman Jagung Akibat Pengaruh Dosis Kapur Dengan Metode Perhitungan Kebutuhan Kapur

\begin{tabular}{lcc}
\hline \multicolumn{1}{c}{ Dosis Kapur } & \multicolumn{3}{c}{ Parameter Pengujian } \\
\cline { 2 - 3 } Dengan Metode & Kadar K $(\%)$ & Serapan K $(\mathrm{g})$ \\
\hline 1. Corey & 1,41 & $0,15 \quad \mathrm{a}$ \\
2. Al-dd & 1,38 & $0,20 \quad$ ab \\
3. Knooti & 1,30 & $0,22 \quad \mathrm{~b}$ \\
\hline $\mathrm{BNT}_{0,05}$ & - & 0,06 \\
\hline
\end{tabular}

Ket: Angka yang diikuti oleh huruf yang sama pada kolom yang sama berbeda tidak nyata pada $\mathrm{BNT}_{0,05}$

Berdasarkan Tabel diatas, rata-rata serapan $\mathrm{K}$ tertinggi dijumpai pada dosis kapur dengan metode Knooti $(0,22 \mathrm{~g})$ yang tidak berbeda nyata dengan metode Al-dd (0,20 g), tetapi berbeda nyata dengan metode Corey $(0,15 \mathrm{~g})$. Rata-rata kadar $\mathrm{K}$ akibat perlakuan dosis kapur dengan metode perhitungan Corey $(1,41 \%)$, sedangkan yang terendah yaitu metode Knooti $(1,30 \%)$. Menurut Jones (1967) kadar K (\%) pada tanaman jagung yang memiliki kadar hara > 2,50 dikategorikan sangat tinggi, 2,26 - 2,50 dikategorikan tinggi, 1,71 - 2,25 dikategorikan sedang, 1,26 - 1,70 dikategorikan rendah dan jika nilai $\mathrm{K}<1,25$ dikategorikan sangat rendah. Maka rata-rata kadar K (Tabel 9 dan 10) termasuk dalam kriteria rendah dikarenakan memiliki nilai kadar hara $1,26-1,70 \%$. Ketersediaan hara $\mathrm{K}$ untuk tanaman tidak hanya ditentukan oleh konsentrasi dalam tanah, tapi juga oleh faktor lainnya. Mutscher (1995) menyatakan bahwa faktor-faktor yang mempengaruhi ketersediaan hara kalium tanaman antara lain jenis dan kadar mineral liat, KTK tanah, interaksi dengan kation lain, kadar air dan lain-lain. Serapan kalium oleh tanaman tidak hanya tergantung pada konsentrasi kalium dalam tanah, tapi juga pada komposisi kation-kation dalam tanah. Keberadaan $\mathrm{NH}_{4}{ }^{+}$, $\mathrm{Ca}^{2+}$ atau $\mathrm{Mg}^{2+}$ yang berlebihan dalam tanah akan mengganggu serapan kalium (Laegreid et 
al., 1999). Rendahnya hara kalium diduga karena interaksi unsur kalium dengan unsur lainnya terutama dengan $\mathrm{Ca}$ dan $\mathrm{Mg}$.

\section{Hasil Jagung \\ Panjang Tongkol (cm)}

Hasil uji $\mathrm{F}$ menunjukkan bahwa jenis kapur, dosis kapur dengan metode perhitungan kapur dan interaksi kedua perlakuan tersebut berpengaruh nyata terhadap panjang tongkol jagung. Rata-rata panjang tongkol jagung akibat pemberian beberapa jenis kapur dan dosis dengan metode perhitungan yang berbeda disajikan pada Tabel 8 .

Tabel 7. Rata-rata Panjang Tongkol Jagung Akibat Pemberian Beberapa Jenis dan Metode Perhitungan Kebutuhan Kapur

\begin{tabular}{lccc}
\hline Dosis Kapur Dengan & \multicolumn{3}{c}{ Jenis Kapur } \\
\cline { 2 - 4 } Metode & 1. Dolomit & 2. Kalsit & 3. Gypsum \\
\hline 1. Corey & $24,12 \mathrm{a}$ & $25,70 \mathrm{a}$ & $26,46 \mathrm{a}$ \\
& $\mathrm{B}$ & $\mathrm{B}$ & $\mathrm{A}$ \\
2. Al-dd & $19,05 \mathrm{a}$ & $21,37 \mathrm{a}$ & $25,73 \mathrm{~b}$ \\
& $\mathrm{~A}$ & $\mathrm{~A}$ & $\mathrm{~A}$ \\
3. Knooti & $16,41 \mathrm{a}$ & $25,87 \mathrm{~b}$ & $27,73 \mathrm{~b}$ \\
& $\mathrm{~A}$ & $\mathrm{~B}$ & $\mathrm{~A}$ \\
\hline $\mathrm{BNT}_{0,05}$ & & 3,28 & \\
\hline
\end{tabular}

Ket: Angka-angka yang diikuti oleh huruf yang sama berbeda tidak nyata pada Uji $\mathrm{BNT}_{0,05}$, huruf kecil dibaca horizontal dan huruf besar dibaca vertikal.

Berdasarkan Tabel 8 rata-rata panjang tongkol jagung tertinggi dijumpai pada perlakuan jenis kapur gypsum dengan metode Knooti $(27,73 \mathrm{~cm})$. Sedangkan panjang tongkol jagung terendah dijumpai pada perlakuan jenis kapur dolomit dengan dosis kapur dihitung dengan metode Knooti $(16,41 \mathrm{~cm})$. Panjang tongkol jagung sangat erat kaitannya dengan ketersediaan unsur hara dalam tanah, adapun salah satu penentu ketersediaan unsur hara dalam tanah adalah derajat kemasaman (pH) suatu tanah. Menurut Havlin et al., (2005) bahwa $\mathrm{pH}$ tanah optimum untuk pertumbuhan jagung berkisar antara 5,5-6,5, kondisi $\mathrm{pH}$ tanah tersebut sangat berhubungan dengan ketersediaan unsur hara di larutan tanah. Sesuai dengan penelitian Amelia (2017), pH tanah akibat pemberian beberapa jenis kapur dengan metode berbeda memperlihatkan kenaikan nilai $\mathrm{pH}$ dari proses inkubasi sampai dengan 7 minggu setelah tanam, sehingga kandungan Al-dd tanah menjadi menurun. Pemberian gypsum menghasilkan panjang tongkol yang terbaik diantara jenis kapur lainnya baik dengan metode Corey, Al-dd maupun Knooti.

\section{Berat Tongkol Berkelobot (g)}

Hasil uji F menunjukkan bahwa jenis kapur dan dosis kapur dengan berbagai metode perhitungan menunjukkan pengaruh sangat nyata sedangkan interaksi kedua perlakuan tersebut berpengaruh nyata terhadap berat tongkol jagung berkelobot. Rata-rata berat tongkol jagung berkelobot akibat pemberian beberapa jenis kapur dan dosis dengan metode perhitungan yang berbeda disajikan pada Tabel 9. 
Tabel 8. Rata-rata Berat Tongkol Jagung Berkelobot Akibat Pemberian Beberapa Jenis dan Metode Perhitungan Kebutuhan Kapur

\begin{tabular}{lccc}
\hline Dosis Kapur Dengan & \multicolumn{3}{c}{ Jenis Kapur } \\
\cline { 2 - 4 } Metode & 1. Dolomit & 2. Kalsit & 3. Gypsum \\
\hline 1. Corey & $150,63 \mathrm{a}$ & $141,89 \mathrm{a}$ & $169,72 \mathrm{a}$ \\
& $\mathrm{B}$ & $\mathrm{B}$ & $\mathrm{A}$ \\
2. Al-dd & $52,75 \mathrm{a}$ & $84,82 \mathrm{a}$ & $130,35 \mathrm{~b}$ \\
& $\mathrm{~A}$ & $\mathrm{~A}$ & $\mathrm{~A}$ \\
3. Knooti & $51,41 \mathrm{a}$ & $139,42 \mathrm{~b}$ & $148,84 \mathrm{~b}$ \\
& $\mathrm{~A}$ & $\mathrm{~B}$ & $\mathrm{~A}$ \\
\hline $\mathrm{BNT}_{0,05}$ & & 42,69 & \\
\hline
\end{tabular}

Ket: Angka-angka yang diikuti oleh huruf yang sama berbeda tidak nyata pada Uji $\mathrm{BNT}_{0,05}$, huruf kecil dibaca horizontal dan huruf besar dibaca vertikal.

Berdasarkan tabel diatas, ternyata jenis kapur gypsum dengan metode Corey menunjukkan berat tongkol jagung berkelobot terbaik $(169,72 \mathrm{~g})$ dari perlakuan lainnya. Sedangkan berat tongkol berkelobot terendah dijumpai pada perlakuan jenis kapur dolomit dengan metode Knooti (51,41 g). Adanya peningkatan hasil jagung, tidak lepas dari peranan kapur untuk mendapatkan unsur hara makro dan mikro yang diserap sepanjang masa pertumbuhannya dalam pembentuk tongkol dan pengisian biji (Harjadi, 2002). Hasil penelitian Amelia (2017), nilai $\mathrm{pH}$ akibat pemberian dolomit dengan metode Corey, Al-dd dan Knooti diperoleh nilai $\mathrm{pH}$ 6,99, 6,48 dan 6,77. Nilai $\mathrm{pH}$ akibat pemberian kalsit secara berurutan yaitu 7,05, 6,68 dan 6,72. Nilai $\mathrm{pH}$ akibat pemberian gypsum secara berurutan yaitu $5,95,6,44$ dan 6,28. Berdasarkan nilai $\mathrm{pH}$ diatas menunjukkan bahwa pemberian gypsum merupakan $\mathrm{pH}$ yang optimum untuk pertumbuhan tanaman jagung. Menurut Havlin et al., (2005) bahwa $\mathrm{pH}$ tanah optimum untuk pertumbuhan jagung berkisar antara 5,5-6,5, kondisi $\mathrm{pH}$ tanah tersebut sangat berhubungan dengan ketersediaan unsur hara di larutan tanah.

\section{Berat Tongkol Tanpa Kelobot (g)}

Hasil uji F menunjukkan bahwa jenis kapur, dosis kapur dengan metode perhitungan dan interaksi kedua perlakuan tersebut berpengaruh sangat nyata terhadap berat tongkol tanpa kelobot. Rata-rata berat tongkol jagung tanpa kelobot akibat pemberian beberapa jenis kapur dengan metode yang berbeda disajikan pada Tabel 9.

Tabel 9. Rata-rata Berat Tongkol Jagung Tanpa Kelobot Akibat Pemberian Beberapa Jenis dan Metode Perhitungan Kebutuhan Kapur

\begin{tabular}{lccc}
\hline Dosis Kapur Dengan & \multicolumn{3}{c}{ Jenis Kapur } \\
\cline { 2 - 4 } Metode & 1. Dolomit & 2. Kalsit & 3. Gypsum \\
\hline 1. Corey & $90,21 \mathrm{a}$ & $83,11 \mathrm{a}$ & $99,75 \mathrm{a}$ \\
& $\mathrm{B}$ & $\mathrm{B}$ & $\mathrm{B}$ \\
2. Al-dd & $38,61 \mathrm{a}$ & $57,51 \mathrm{ab}$ & $76,08 \mathrm{~b}$ \\
& $\mathrm{~A}$ & $\mathrm{~A}$ & $\mathrm{~A}$ \\
3. Knooti & $33,55 \mathrm{a}$ & $80,50 \mathrm{~b}$ & $111,00 \mathrm{c}$ \\
& $\mathrm{A}$ & $\mathrm{B}$ & $\mathrm{B}$ \\
\hline $\mathrm{BNT}_{0,05}$ & & 21,11 & \\
\hline
\end{tabular}

Ket: Angka-angka yang diikuti oleh huruf yang sama berbeda tidak nyata pada Uji $\mathrm{BNT}_{0,05}$, huruf kecil dibaca horizontal dan huruf besar dibaca vertikal. 
Berdasarkan tabel diatas, ternyata jenis kapur gypsum dengan perhitungan Knooti menunjukkan hasil tertinggi (111,0 g). Sedangkan yang terendah adalah pada penggunaan dolomit dengan metode Knooti $(33,55 \mathrm{~g})$. Sama halnya dengan berat tongkol berkelobot, bedanya dengan parameter berat tongkol tanpa kelobot yaitu jagung yang ditimbang tidak dengan kelobotnya. PH optimum merupakan faktor utama dalam pertumbuhan tanaman jagung seperti yang telah dijelaskan diatas, sehingga pemberian gypsum dengan metode Knooti didapatkan hasil yang tebaik diantara pemberian jenis kapur dengan metode lainnya.

\section{Diameter Tongkol Berkelobot (cm)}

Hasil uji F menunjukkan bahwa jenis kapur, dosis kapur dengan metode perhitungan dan interaksi kedua perlakuan tersebut berpengaruh sangat nyata terhadap diameter tongkol berkelobot. Rata-rata diameter tongkol jagung berkelobot akibat pemberian beberapa jenis kapur dengan metode yang berbeda disajikan pada Tabel 10.

Tabel 10. Rata-rata Diameter Tongkol Jagung Berkelobot Akibat Pemberian Beberapa Jenis dan Metode Perhitungan Kebutuhan Kapur

\begin{tabular}{lccc}
\hline $\begin{array}{c}\text { Dosis Kapur Dengan } \\
\text { Metode }\end{array}$ & \multicolumn{3}{c}{ Jenis Kapur } \\
\cline { 2 - 4 } 1. Corey & $4,41 \mathrm{a}$ & 2. Kalsit & 3. Gypsum \\
& $\mathrm{C}$ & $4,36 \mathrm{a}$ & $4,50 \mathrm{a}$ \\
$2 . \mathrm{Al}-\mathrm{dd}$ & $3,44 \mathrm{a}$ & $\mathrm{B}$ & $\mathrm{B}$ \\
& $\mathrm{B}$ & $3,43 \mathrm{a}$ & $4,05 \mathrm{~b}$ \\
3. Knooti & $2,87 \mathrm{a}$ & $\mathrm{A}$ & $\mathrm{A}$ \\
& $\mathrm{A}$ & $4,19 \mathrm{~b}$ & $4,19 \mathrm{~b}$ \\
$\mathrm{BNT}_{0,05}$ & & $\mathrm{~B}$ & $\mathrm{AB}$ \\
\hline
\end{tabular}

Ket: Angka-angka yang diikuti oleh huruf yang sama berbeda tidak nyata pada Uji $\mathrm{BNT}_{0,05}$, huruf kecil dibaca horizontal dan huruf besar dibaca vertikal.

Berdasarkan tabel diatas, rata-rata diameter tongkol jagung berkelobot tertinggi dijumpai pada perlakuan jenis kapur gypsum dengan metode Corey $(4,50 \mathrm{~cm})$. Sedangkan diameter tongkol jagung berkelobot terendah dijumpai pada perlakuan jenis kapur dolomit dengan metode Knooti $(2,87 \mathrm{~cm})$. Pada perlakuan jenis kapur gypsum dengan ketiga metode perhitungan kebutuhan kapur didapatkan nilai yang tertingi dari jenis kapur lainnya. Sesuai dengan penelitian Amelia (2017) bahwa $\mathrm{pH}$ tanah pada perlakuan gypsum berada pada kisaran $\mathrm{pH}$ tanah optimum $(5,5-6,5)$ untuk tanaman jagung sehingga penyerapan hara untuk proses pembentukan tongkol lebih baik dari yang lain.

\section{Diameter Tongkol Tanpa Kelobot (cm)}

Hasil uji F menunjukkan bahwa jenis kapur dan dosis kapur dengan metode perhitungan menunjukkan pengaruh sangat nyata sedangkan interaksi kedua perlakuan tersebut berpengaruh nyata terhadap diameter tongkol jagung tanpa kelobot. Rata-rata diameter tongkol jagung tanpa kelobot akibat pemberian beberapa jenis kapur dengan metode yang berbeda disajikan pada Tabel 11 . 
Tabel 11. Rata-rata Diameter Tongkol Jagung Tanpa Kelobot Akibat Pemberian Beberapa Jenis dan Metode Perhitungan Kebutuhan Kapur

\begin{tabular}{lccc}
\hline \multirow{2}{*}{$\begin{array}{c}\text { Dosis Kapur Dengan } \\
\text { Metode }\end{array}$} & \multicolumn{3}{c}{ Jenis Kapur } \\
\cline { 2 - 4 } 1. Corey & $3,79 \mathrm{a}$ & 2. Kalsit & 3. Gypsum \\
& $\mathrm{C}$ & $3,78 \mathrm{a}$ & $3,74 \mathrm{a}$ \\
$2 . \mathrm{Al}-\mathrm{dd}$ & $3,12 \mathrm{a}$ & $\mathrm{B}$ & $\mathrm{A}$ \\
& $\mathrm{B}$ & $3,23 \mathrm{a}$ & $3,49 \mathrm{a}$ \\
3. Knooti & $2,66 \mathrm{a}$ & $\mathrm{A}$ & $\mathrm{A}$ \\
& $\mathrm{A}$ & $3,61 \mathrm{~b}$ & $3,58 \mathrm{ab}$ \\
$\mathrm{BNT}_{0,05}$ & $\mathrm{AB}$ & $\mathrm{A}$ \\
\hline Ket : Angka-angka yang diikuti oleh huruf yang sama berbeda tidak nyata pada Uji & $\mathrm{BNT}_{0,05}$, huruf kecil dibaca \\
\multicolumn{2}{c}{ horizontal dan huruf besar dibaca vertikal. }
\end{tabular}

Berdasarkan tabel diatas, ternyata jenis kapur dolomit dengan metode perhitungan Corey menunjukkan diameter tongkol jagung tanpa kelobot yang tertinggi yaitu $3,79 \mathrm{~cm}$. Sedangkan diameter tongkol jagung tanpa kelobot terendah adalah pada penggunaan dolomit dengan metode Knooti dengan nilai 2,66 cm.

\section{SIMPULAN DAN SARAN}

Kadar N dan Serapan K tanaman jagung pada Ultisol berbeda akibat perbedaan metode perhitungan kebutuhan kapur, dimana metode Corey menunjukkan kadar dan serapan yang paling baik. Komponen hasil jagung bervariasi akibat perbedaan metode perhitungan kebutuhan kapur dan jenis kapur yang digunakan. Komponen hasil jagung tertinggi dijumpai pada metode Corey dengan jenis kapur gypsum.

\section{DAFTAR PUSTAKA}

Amelia, D. 2017. Analisis Metode Kebutuhan Kapur Pada Ultisol dan Hubungannya Dengan Sifat Kimia Tanah dan Pertumbuhan Jagung (Zea mays L.). Fakultas Pertanian, Universitas Syiah Kuala, Banda Aceh.

Amien, L.I., C.L.I., Evensen, and R.S. Yost. 1990. Performance of some improved peanut cultivars on an acid soil of West Sumatra. Pemberitaan Penelitian Tanah dan Pupuk 9: $1-7$.

Gardner, F. P., R. Brent Pearce, \& Roger L. Mitchell. 1991. Fisiologi Tanaman Budidaya. Universitas Indonesia Press. Jakarta.

Hardjowigeno, S. 1992. Ilmu Tanah. Akamedika Pressindo. Jakarta.

Havlin, J. L. J. D. Beaton, S. L. Tisdale and WL Nelson. 2005. Soil Fertility and Fertilizers An Introduction to Nutrient Management. Seventh Edition. Pearson Education Inc. Upper Saddie River, New Jersey.

Homer ER. 2008. The effect of nitrogen application timing on plant available phosphorus.

Thesis. Graduate School of The Ohio State University. USA.

Jones, U.S. 1967. Fertilizer and Soil Fertility. Reston Pub. Co. Virginia.

Laegreid, M., O. C. Bockman and O. Kaarstad. 1999. Agriculture, Fertilizers and the Environment. CABI Publishing. New York. 294 p.

Mutscher, H. 1995. Measurement and Assessment of Soil Potassium. IPI Res. Topics No.4. Int. Potash Inst.

Notohadiprawiro, T. 1983. Persoalan Tanah Masam dalam Pembangunan Pertanian di Indonesia. Fakultas Pertanian, Universitas Gadjah Mada, Yogyakarta.

Serapan Hara dan Hasil Jagung (Zea mays L.) Akibat Pemberian Berbagai Jenis dan Metode Perhitungan Kebutuhan Kapur pada Ultisol 
Purbajayanti, E. D., B. A. Kristanto., R. Trimulatsih., S. Anwar., F. Kusmiyati dan Karno. 2002. Ilmu Tanah dan Kesuburan. Jurusan Nutrisi dan Makanan Ternak, Universitas Diponegoro, Semarang.

Purwono dan R. Hartono, 2011. Bertanam Jagung Unggul. Penebar Swadaya. Jakarta. 64 hal. Sanchez, P. A. 1992. Sifat dan Pengolahan Tanah Tropika. Penerbit ITB, Bandung.

Sarasutha, IG.P. 2002. Kinerja usaha tani dan pemasaran jagung di sentra produksi. Jurnal Penelitian dan Pengembangan Pertanian 21(2): 39-47.

Tisdale, S.L., W.L. Nelson \& J.D. Beaton. 1985. Soil Fertility and Fertilizers. $4^{\text {th }}$ ed. MacMillan Publ. Co., Inc., New York.

Wang YP, BZ Houlton and CB Field. 2007. A model of biogeochemical cycles of carbon, nitrogen, and phosphorus including symbiotic nitrogen fixation and phosphatase production. Global Biogeochemical Cycles 21, 1018-1029. 